\title{
Ultraslow spreading, ridge relocation and compressional events in the East Arctic region: A link to the Eurekan orogeny?
}

\author{
C. Gaina ${ }^{1} \cdot$ A. M. Nikishin ${ }^{2}$ E. I. Petrov ${ }^{3}$
}

Received: 7 September 2015/Accepted: 14 October 2015/Published online: 23 November 2015

(C) Springer-Verlag Berlin Heidelberg 2015

\begin{abstract}
New and available geophysical data from the Eastern Arctic (around the Siberian tip of the Lomonosov Ridge) indicate a change in the tectonic regime at the Eocene time. Oceanic crust identified on the new seismic reflection data in the Amundsen Basin displays an asymmetric fabric also visible in the gravity and magnetic gridded data. Tentative dating of the weak magnetic anomalies suggests asymmetric spreading or ridge relocation from ca. 49 to $33 \mathrm{Ma}$. Three seismic reflection transects through the Laptev Sea, Lomonosov Ridge and adjacent basins image several compressional features, most likely initiated in the Eocene. According to a regional plate tectonic model, the Greenland plate has pushed the Lomonosov Ridge by ca. $30 \mathrm{~mm} /$ year from 54 to $49 \mathrm{Ma}$ and by ca. $13.5 \mathrm{~mm} /$ year afterwards, until Early Miocene. We suggest that intraplate stresses triggered by the Eocene to Oligocene northern movement of the Greenland plate and subsequent collision with the North American plate that created the Eurekan deformation, have propagated through the Arctic region and affected part of the East Siberian Shelf, Podvodnikov Basin, Laptev Sea and modified the spreading direction in the eastern Eurasia Basin. We estimate that these changes
\end{abstract}

Electronic supplementary material The online version of this article (doi:10.1007/s41063-015-0006-8) contains supplementary material, which is available to authorized users.

C. Gaina

carmen.gaina@geo.uio.no

1 Department of Geosciences, Centre for Earth Evolution and Dynamics (CEED), University of Oslo, Oslo, Norway

2 Geological Faculty, Moscow State University, Moscow, Russia

3 Federal Agency for Subsoil Use, Moscow, Russia started at the same time as the peak compressional phase in North Greenland dated $49-47 \mathrm{Ma}$ and lasted until Oligocene time when the large-scale tectonic regime changed by incorporating Greenland into the North American plate.

Keywords Arctic - Lomonosov - Eurasia Basin .

Magnetic anomalies · Compression · Eurekan deformation

\section{Introduction}

The Arctic realm (Fig. 1a) received considerable attention from the scientific community in the last two decades, partly due to numerous data acquisition campaigns meant to feed geological knowledge to the UNCLOS (United Nation Convention for the Law of the Sea) applications, and partly because the sea ice coverage has been recently reduced and therefore the success and quality of data collection increased. Until recently, the tip of the Eurasian Basin-the youngest oceanic basin in the Arctic which hosts the slowest seafloor spreading ridge on Earth-has been scarcely studied (e.g., [19, 38]). Its connection with the continental margins-the sliver complex of the Lomonosov Ridge on one flank, and the Kara and Laptev seas extended continental shelves on the conjugate flank (Fig. 1), has also received only limited attention. On the other side of the Lomonosov Ridge, the Podvodnikov Basin and the East Siberian shelf (Fig. 1) may have been formed prior to the establishment of seafloor spreading in the Eurasian Basin, but the timing, nature and exact relationship between the two basins flanking the East Lomonosov Ridge are still unresolved.

In this contribution we aim to discuss and attempt to shed light on Cenozoic structures observed in the area 
between the western part of Podvodnikov Basin and Kara Sea margin based on new Russian seismic lines and available potential field data and kinematic models. In particular, we will focus on a series of compressional features imaged by the new seismic data and discuss possible scenarios to explain their formation during the evolution of the Eurasian Basin.

\section{Tectonic setting of the eastern Eurasian Basin}

Rifting and seafloor spreading in the Arctic region led to the formation of several deep water basins (Canada, Podvodnikov, and Makarov-as part of the Amerasia Basin, and the Eurasian Basin) floored by extended continental crust, exhumed subcontinental mantle and oceanic crust
Fig. 1 a, b Bathymetry (ETOPO1, [1]); c Free air gravity anomaly (DTU10, [3]); d Magnetic anomaly [19] and gravity anomaly (from c) contours superimposed; and e Gravity anomaly derivative imaging the orientation of small scale crustal features (also indicated by thin black lines within the polygon in panels b and c). The magenta polygon in panel a shows the area detailed in panels $\mathbf{b}-\mathbf{d}$. The white (black in e) dashed line polygon shows the study area. $P B$ is Podvodnikov Basin and $M B$ is the Makarov Basin. In $\mathbf{d}$, $P$ indicates positive magnetic anomaly segment and

$N$ negative magnetic anomaly segment of the Gakkel Ridge in the studied area. Note the oblique orientation relative to the Gakkel Ridge of two features visible in the gravity data (labelled $R a$-Ridge in the Amundsen Basin, and $R n-$ ridge in the Nansen Basin). The contour of these features and adjacent contours are shown in white in $\mathbf{d}$
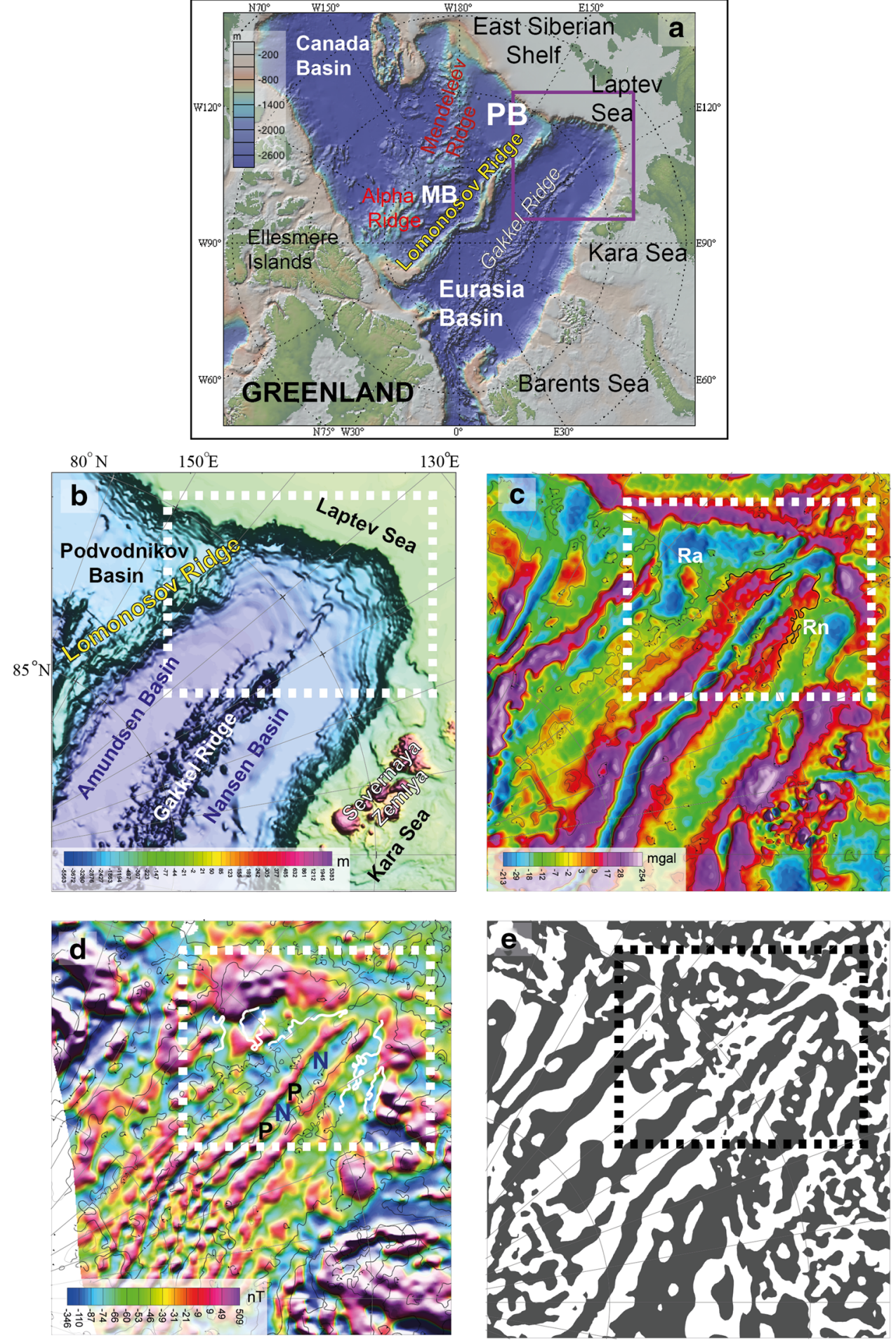
(see review papers by $[18,31,34]$ ). It is now postulated that the oldest oceanic basin-the Canada Basin-is formed by all three types of crusts mentioned above (e.g., [32]). At the other end of the spectrum is the Eurasian Basin, which is the result of seafloor spreading, albeit an extremely slow seafloor spreading, in particular in the last 33 Ma (e.g., [8]). The Makarov Basin is a small, but very deep basin and its basement is probably partly continental (e.g., [27, 31]). The Podvodnikov Basin is floored by ca. $20 \mathrm{~km}$ thick crust (e.g., [28]), which led some authors to propose that this is entirely stretched continental crust (e.g., [31]). Other studies suggest that the basin has both oceanic and continental crust, with Jokat and Ickrath [22] suggesting that ca. $50 \%$ of its basement along the $81^{\circ} \mathrm{N}$ transect is stretched continental crust (note that they refer to the Podvodnikov Basin as the Makarov Basin). In this paper we will discuss the region that contains the southern part of the Podvodnikov Basin and the eastern-northeastern part of the Eurasian Basin and surrounding regions: the East Siberian Shelf, the Lomonosov Ridge and part of the Laptev Sea (Fig. 1).

The continental nature of the Lomonosov Ridge has been already established more than three decades ago by noticing the similarities with the Barents and Kara seas margins [13], the crustal thickness which exceeds $20 \mathrm{~km}$ (e.g., [23, 27, 36]); and finally continental rocks recovered from its flanks (e.g., [36]). Bathymetry, gravity and seismic data indicate that the ridge broadens towards the Laptev Shelf (e.g., [7, 24]); see Fig. 1). The tectonic link between continental rifting, break-up and seafloor spreading in the Eurasian Basin and the Laptev-East Siberian rift system has been discussed in several studies. Sekretov, [38] interpreted the MAGE seismic reflection data set that covered $76-80^{\circ} \mathrm{N}$ region in the Eurasian Basin-Laptev Sea area, and identified a rifted valley covered by sediments at the tip of the Eurasian Basin as the buried continuation of the Gakkel Ridge. He proposed that this ridge segment was only recently reactivated (probably at 3-1 Ma), after a standstill of almost 30 million years. This study established the limit between continental and oceanic crust and sedimentary package thickness and succession and emphasized the asymmetric shape of this part of the Eurasian Basin. Drachev et al. [11] analysed German-Russian seismic data and satellite gravity data and suggested that the eastward decrease of the sedimentary cover in the Laptev Sea indicates a rejuvenation of the rifts in the same direction. They also reiterated that the Eurasian Basin and the Laptev Sea rift system are divided by a transform fault called the "Northern Fracture", "Severnyi Transfer" or the "Khatanga-Lomonosov Transform". Franke et al. [15] and later Franke and Hinz [14] used an extended seismic dataset in the Laptev Sea and adjacent East Siberian shelf and suggested that: (1) the Laptev Sea rift system was developed east of the transfer zone which links the Gakkel Ridge to the Laptev Sea Rift, with rifting episodes somehow disconnected from the evolution of the Gakkel Ridge, and (2) the East Siberian shelf developed as an epicontinental platform that subsided independently of the Laptev Sea Rift system. A recently acquired high-resolution seismic reflection dataset led Nikishin et al. [31] to suggest that the pre-Eocene system of continental grabens observed on the Lomonosov Ridge and Laptev-East Siberian seas shelves are part of a common rift system.

\section{A Mid-Eocene-Oligocene change in spreading direction in the East Eurasian Basin}

Thick sediment cover and sparse geophysical data has hindered a detailed interpretation of the age and structure of the Eurasian basin region next to the Russian shelves (Fig. 1). The age and structure of the oceanic crust has been relying so far on regional or global magnetic and gravity anomaly gridded data (e.g., [2, 39]). The original Russian aeromagnetic data have been used only once for a detailed analysis of oceanic crust in the Eurasian Basin by Glebovsky et al. [19]. However, their model does not extend south of $81^{\circ} \mathrm{N}$ as the magnetic anomaly pattern seems to lose the linear pattern. A closer inspection of the geometry of the crust as illustrated by the gravity anomalies (DTU10, Andersen [3]) points to a rhomboid-like shaped area where the Gakkel ridge propagated obliquely relative to a pre-existent crustal fabric (Fig. 1).

In the absence of original aeromagnetic track data, we use a magnetic anomaly grid based on these data, but upward continued to $5 \mathrm{~km}$. Note that this grid corrects an artificial shift of the Gakkel Ridge axis observed in the CAMP-GM compilation [17] as shown by Glebovsky et al. [20]. The nature of the crust in the easternmost Eurasian Basin is revealed by the new seismic data (Figs. 2, 3), and clearly shows oceanic crust pattern with rough basement reflectors and a topography that subsides towards the basin margins. Potential field data (isostatic gravity anomaly from World Gravity Project, Balmino et al. [5]; magnetic data-an amendment to the [17] CAMPGM-M map by Glebovsky et al. [20], bathymetry (ETOPO1 version that incorporates IBCAO3 grid, [1] and sediment thickness (modified grid of Kaminsky et al. [26] and Kashubin et al. [25] by LebedevaIvanova et al. [29]) grids were sampled along four profiles and stacked for further interpretation (Fig. 4). From profile examination, we note that: (1) present day Gakkel ridge valley has high positive anomaly on profile 1 , lower positive anomalies on profiles 2 and 3, and a negative magnetic anomaly, on profile 4 which is closer to the tip of the Eurasian Basin; (2) symmetric spreading seems to be confined for 60-70 km away from the Gakkel Ridge, beyond that there 


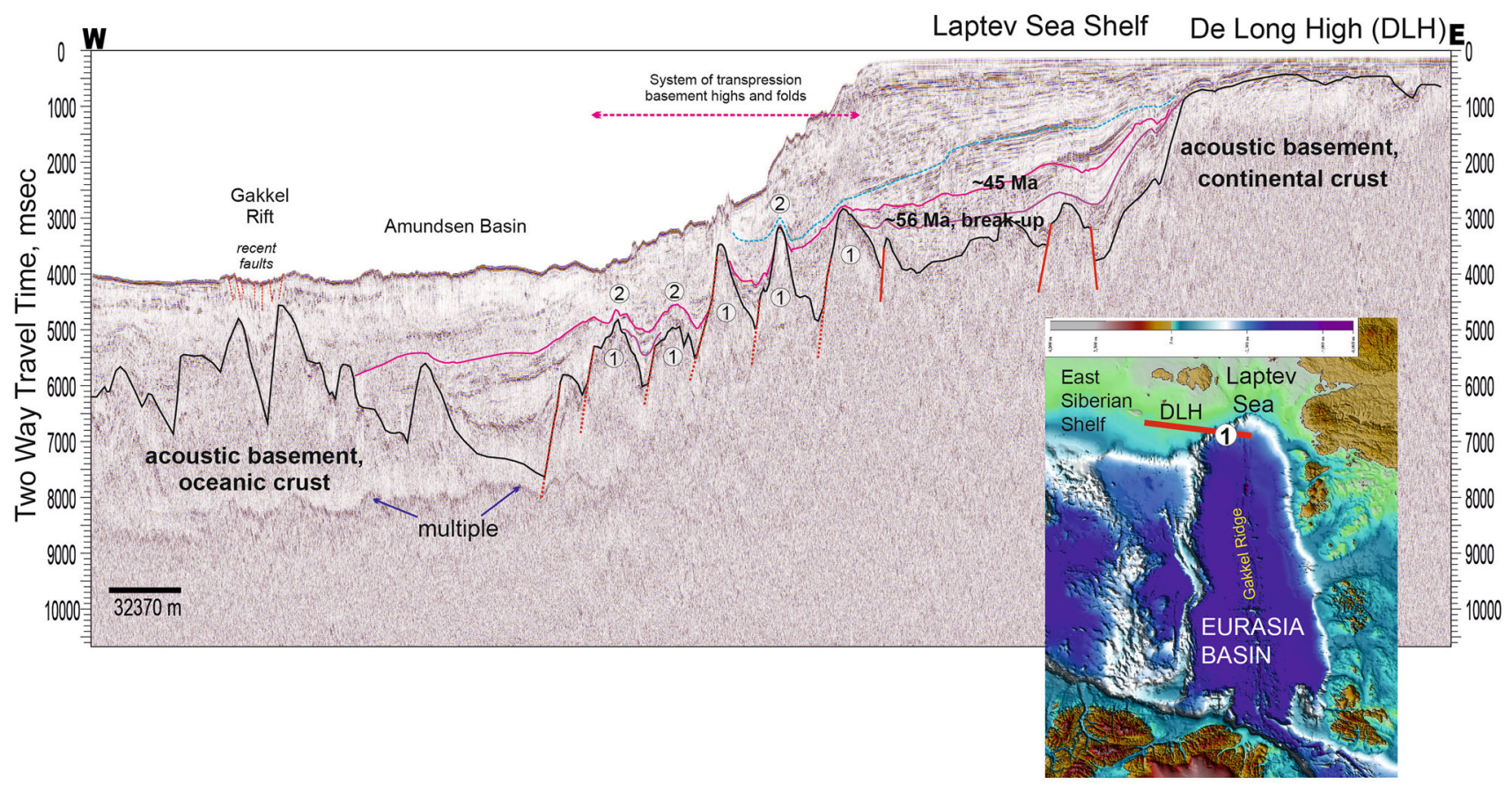

Fig. 2 Fragment of the seismic line Arktika-2012-16. We interpret uplift of continental slope basement highs possible around $45 \mathrm{Ma}$. We postulate that this deformation was due to a transpressional regime and may have lasted until to Oligocene-Neogene times. We label "1" the original basement highs which were formed by extension related

are no identifiable symmetric magnetic anomalies, and (3) more oceanic crust seems to be present on the Amundsen Basin flank than on the Nansen flank between 80.5 and $78^{\circ} \mathrm{N}$ (see shaded regions on maps and profiles 3 and 4 in Fig. 4). These observations point to either asymmetric seafloor spreading or a relocation of the mid-ocean ridge through time and crust transfer from the Eurasian to the North American plate (whose continental margin in this region is the Lomonosov Ridge). A tentative interpretation of the low-amplitude magnetic anomalies in the easternmost tip of the Eurasian basin (Figs. 1, 5a) suggests that the ridge may have propagated southward at $\mathrm{C} 22$ time (ca. $49 \mathrm{Ma}$ ) and continued spreading until at least $45 \mathrm{Ma}$ in an oblique direction (relative to the present day Gakkel Ridge). At this time, in the rest of the Eurasian Basin, the spreading rate decreased from about 23-15 mm/year [19], and continued to decrease to less than $10 \mathrm{~mm} /$ year until $33 \mathrm{Ma}$. An asymmetry in the seafloor basement with shallower depth to basement in the Amundsen basin compared to the conjugate Nansen basin has been first reported by Sekretov [38] and confirmed by the new Russian seismic data [31]. Depth to oceanic basement is a proxy to its age and therefore the presence of a wider area of shallow basement in the Amundsen Basin and narrower, deeper Nansen Basin could indicate asymmetry in oceanic accretion.

Based on the asymmetric shape of the easternmost part of the Eurasian Basin, a tentative interpretation of magnetic to break-up, and we label " 2 " anticlines that were formed after breakup, possible in the Eocene. We estimate that the uplift took place after our postulated " $45 \mathrm{Ma}$ " event as these highs and subsequent sedimentation is laying on top of our " $45 \mathrm{Ma}$ " reflector. Uninterpreted seismic line is presented in Supplementary Figure S1

and gravity anomalies on gridded data and along four selected profiles, we suggest that at Mid-Eocene time (C22-C20), the spreading direction changed in this region. A possible relocation of the mid-ocean ridge may have led to additional crust accretion in the Amundsen Basin at the expense of the Nansen basin. By C13 (ca. $33 \mathrm{Ma}$ ), seafloor spreading in the easternmost tip of the Eurasian basin aligned to the same direction as to the ridge segment north of $81^{\circ} \mathrm{N}$ by a gradual clockwise rotation-a direction maintained until present day.

Fig. 3 a Composite seismic line from Russian government projects Arktika-2011, Arktika-2012 and Arktika-2014 covering the tip of the Amundsen Basin, the Laptev Sea and the De Long High on the East Siberian shelf. Our interpretation approach is the same as in Fig. 2. A zoomed-in section where we have interpreted compressional features is also presented. Un-interpreted seismic line is presented in Supplementary Figure S2. b Seismic line Arktika-2014-14 and zoomed-in section. Compression-related features (ca. 45-23 Ma) could be recognized in the continental slope. The numbers in white circles show the following: Unit " 1 " - syntectonic and syncompressional deposition simultaneously with folding in units 2 and 3. Units " 2 " and " 3 " were folded mainly between horizon 45 Ma and "blue" horizon. Unit " 4 "- clinoform type of deposits with paleoslope towards Podvodnikov Basin; note that unit " 2 " was not a topographic high. Unit/event "5"-Unit "2" together with the basement was uplifted before the horizon interpreted as " 23 " Ma. Unit " 6 " erosional surface in the slope; horizon " $23 \mathrm{Ma}$ " was deposited after the end of the Unit " 2 " tectonic uplift 


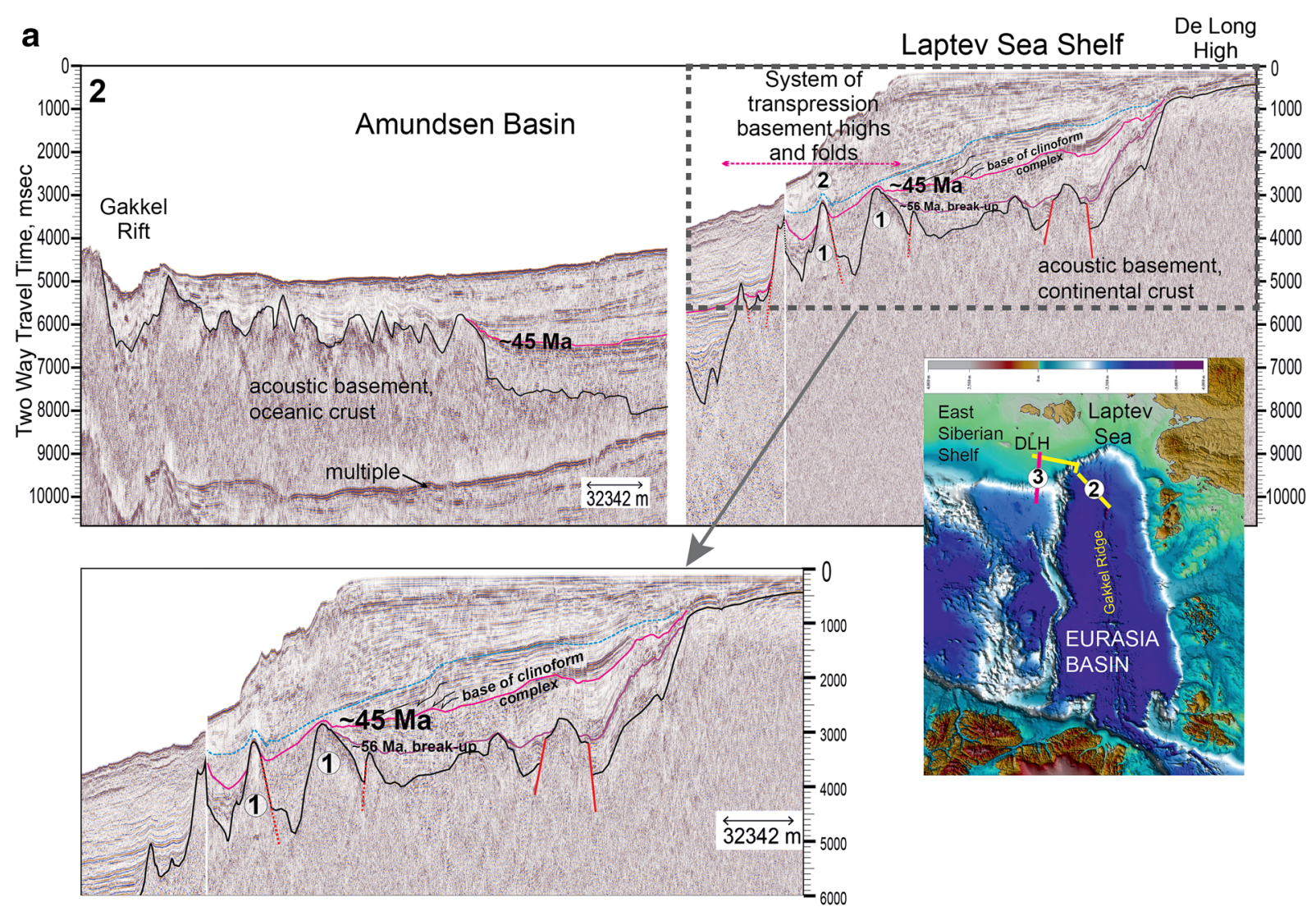

b

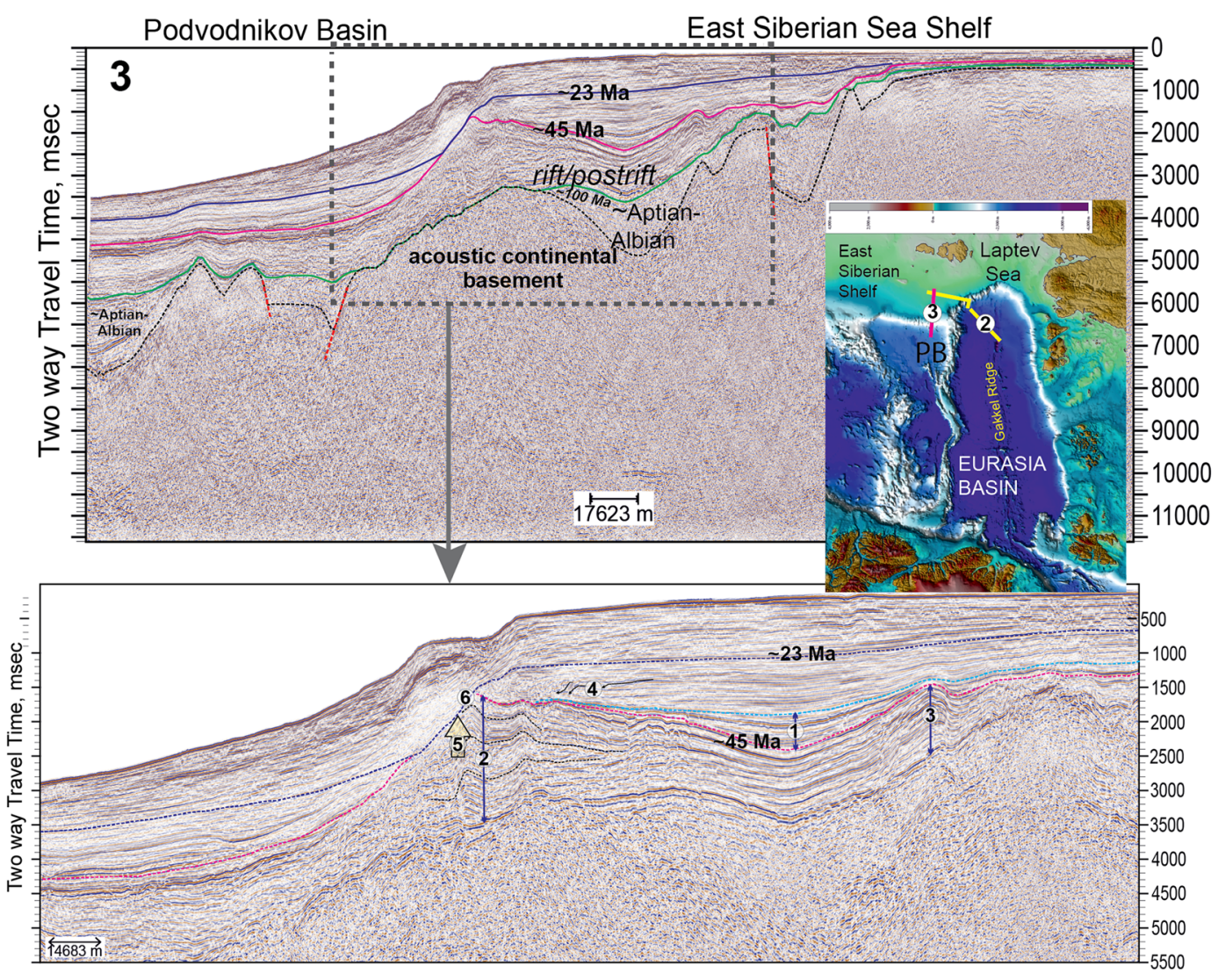


Fig. 4 Upper panels: Magnetic anomaly (left) and free air gravity anomaly (right) as in Fig. 1. Selected profiles are shown as black lines on both maps. 2D profiles extracted from magnetic anomaly grid (red), isostatic gravity grid (green), bathymetry (blue) and sediment thickness (olive) variations in the Amundsen and Nansen subbasins are also shown. Synthetic magnetic anomalies (in magenta) with a symmetric spreading (upper profile) and asymmetric spreading system (lower profile) are shown and used to identify and date the magnetic chrons. For constructing the synthetic magnetic profiles we have used a thin magnetised layer $(0.1$ $\mathrm{km})$, a depth to source of $12 \mathrm{~km}$ (water depth $\sim 3 \mathrm{~km}$, sediment thickness $\sim 4 \mathrm{~km}$, and an upward continuation of $5 \mathrm{~km}$ that corresponds to the magnetic grid used here). The declination and inclination of the magnetic field at the time of data collection are $D=-14$ and $I=$ 64. The paleolatitude and longitude at the time of oceanic crust formation was approximated at 82 degrees north and 105 degrees east, respectively
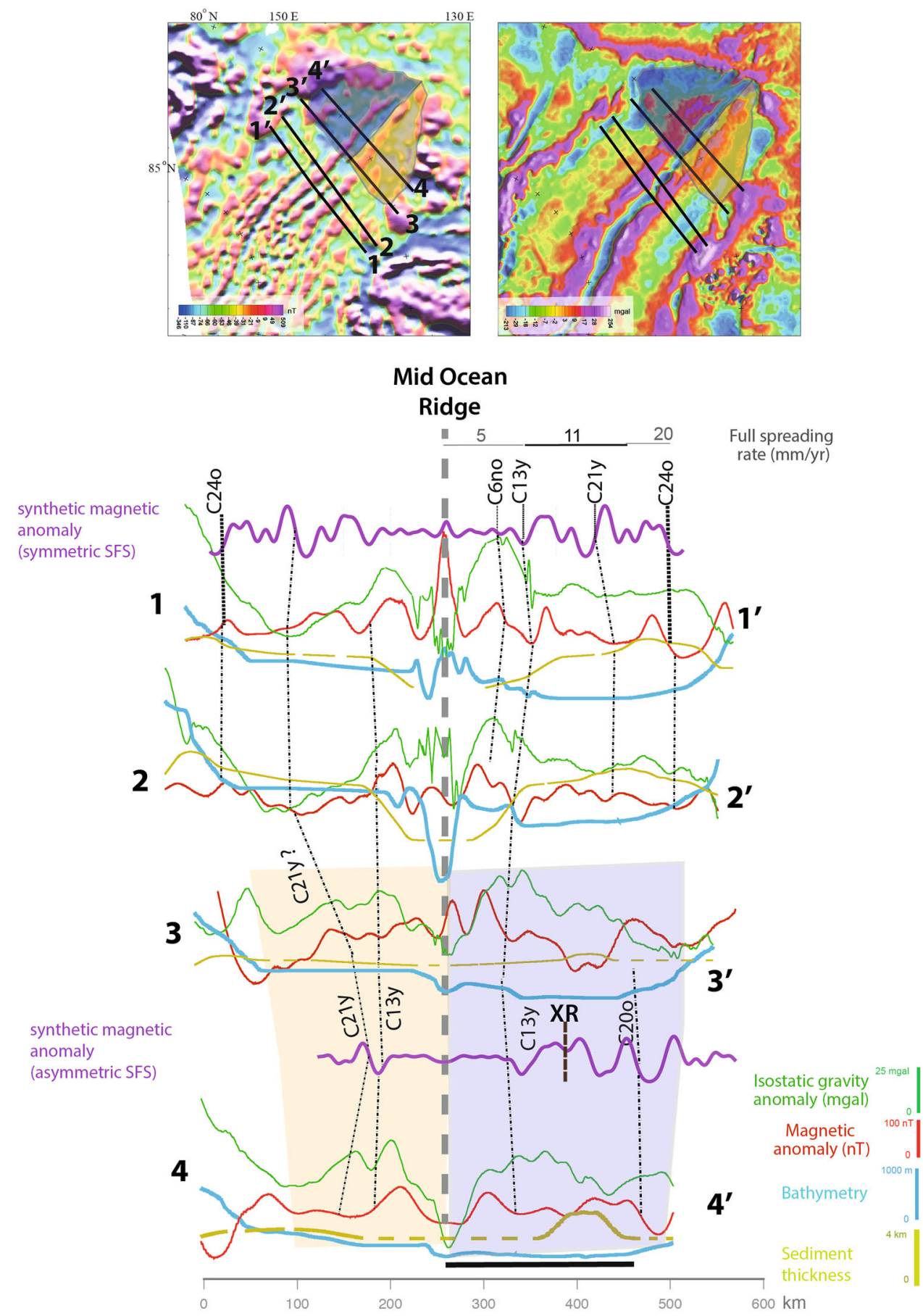

\section{Eocene and post-Eocene compression} on the Lomonosov Ridge: East Siberian ShelfPodvodnikov and East Eurasian basins

Break-up and seafloor spreading in the Eurasian Basin that started in the Late Paleocene (e.g., [6, 19]) established a pervasive extensional regime in the Arctic realm. This is illustrated by the basement structure of continental margins (both Eurasia and smaller tectonic blocks in the Arctic, including the Lomonosov Ridge) and the smooth, undisturbed style of sediment draping observed in the seismic data in most of the Arctic basins (e.g., [12, 24]). However, new seismic data recently acquired by Russian institutes show compressional features in several basins and continental margins. Here we report that several basement highs and folds are observed in the Laptev Sea, at the immediate border with the Eurasian Basin, and in the East Siberian Shelf in the proximity of the Lomonosov Ridge (Figs. 2, 3, 

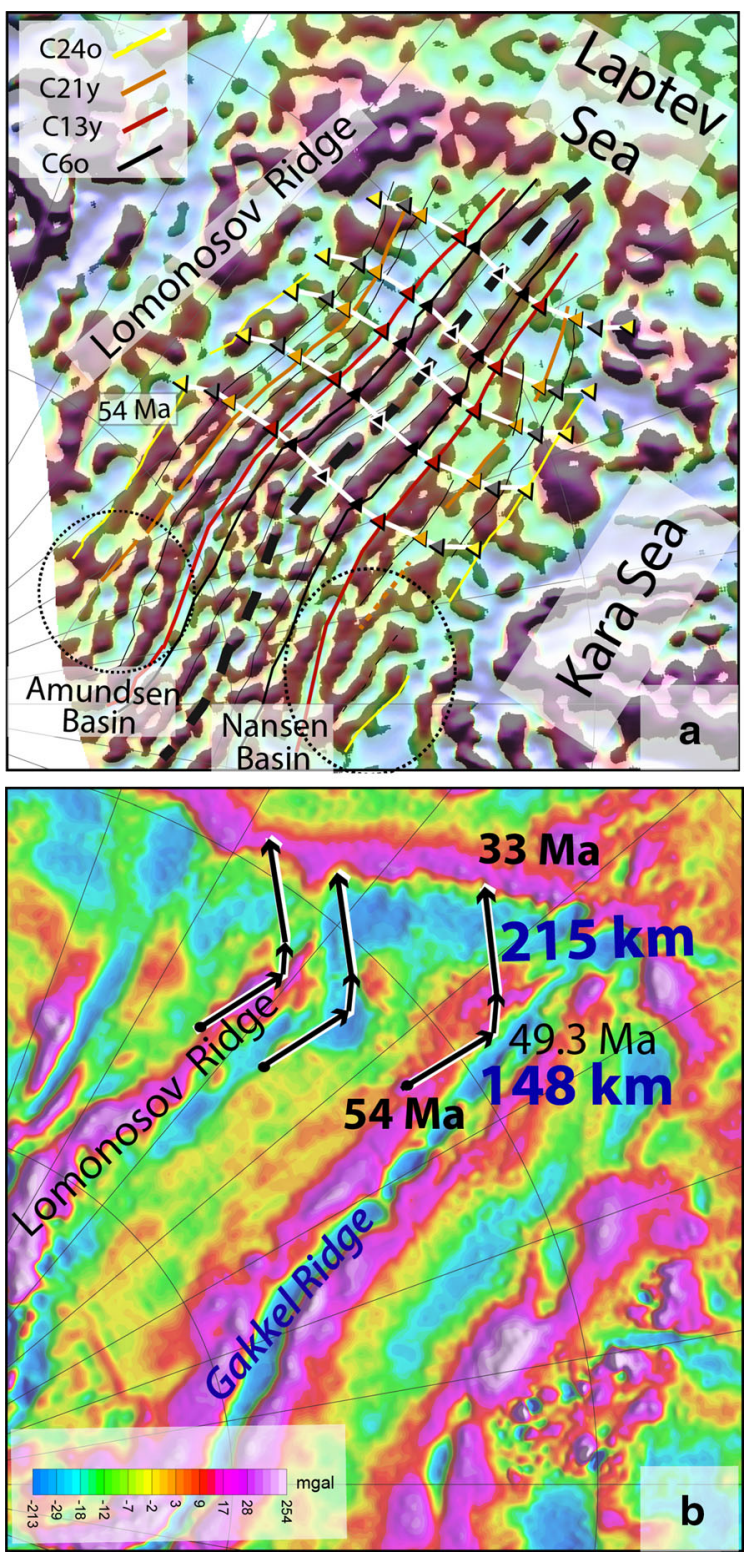

Fig. 5 a Magnetic anomaly grid [19] enhanced by horizontal gradient of the grid that helps detecting the magnetised body edges. Relevant isochrons (lines of equal ages derived from interpretation of magnetic anomaly pattern against a geomagnetic polarity time scale-in this case, Ogg [33] are shown in different colours (see legend). Flowlines computed for a kinematic model [16] with symmetric spreading are shown as white lines. Flowline segments represent small circles computed for stage poles derived from the kinematic model. The triangles indicate the position of the mid ocean ridge on each flank in case of symmetric spreading at chrons C24 old (53.9 Ma), C22 old (49.3 Ma), C21 young (45.7 Ma), C33 young (33.2 Ma), and C6 old (23.2 Ma). b Free air gravity grid (DTU10, [3]) and motion vectors showing the amount of compression and transpression between the Lomonosov Ridge and the East Siberian Shelf/Laptev Sea between ca. 54 and $33 \mathrm{Ma}$. To compute this motion, we assume that the Lomonosov Ridge would have been rigidly attached to Greenland (in other words, the entire northward Greenland motion would have been accommodated between the tip of the Ridge and the continental shelf in this region)
S1-4). A systematic pan-Arctic sedimentary package correlation following distinct seismic reflection character separated by sharp reflectors and linked to the ACEX borehole on the Lomonosov Ridge [4], has proposed ages of unconformities and sedimentary packages [31, 44]. Magnetic anomalies identified in the central Eurasian Basin were also correlated with a series of seismic reflection profiles from the Amundsen Basin as additional constrain on the age model [31]. These studies identified roughly the same seismic reflectors, but differ in their age interpretation. Both studies identify reflectors in the 56-45 Ma interval which are correlated to the ACEX chronostratigraphy (Fig. S5). Based on these estimations, it is suggested that the compressional features identified in the seismic lines crossing the Amundsen Basin and Lomonosov Ridge into the Laptev Sea and East Siberian Shelf were formed not earlier than Mid-Eocene time (approximately $45 \mathrm{Ma}$ ), and some of them may have experienced compression or transpression until Miocene (ca. $23 \mathrm{Ma}$ ) (Figs. 2, 3, S1-4). The interpreted basement highs in the Laptev Sea-East Siberia Sea continental slope were uplifted around $45 \mathrm{Ma}$ and this deformation may have lasted until OligoceneNeogene times. The seismic reflectors in the Cenozoic deposits of the Lomonosov Ridge have sinusoid-like geometry along ridge strike that could have resulted due to compression along the ridge (Fig. S4).

\section{Eurekan orogeny}

As a result of changes in plate tectonics in the North Atlantic that established a triple junction between North America-Iberia spreading, the Labrador Sea and the newly formed NE Atlantic, the Greenland plate started to move northward in the Paleocene time (e.g., [16, 40]). North of Greenland, a number of tectonic blocks, known as the Ellesmere Islands (Fig. 1) and probably attached to the northeastern tip of the North American plate, acted as a buttress between the Greenland plate and the Arctic region (formed, at that time, by an older oceanic domain-the Amerasian Basin, and a number of smaller tectonic blocks, among them-the Lomonosov Ridge). The PaleoceneEocene compression between Greenland and Ellesmere Islands resulted in the so-called "Eurekan" orogeny or deformation and it is now known to have been developed in multiple stages (e.g., [37, 43]). Numerous field campaigns in the last two decades to the Ellesmere islands reported features that document polyphase Eurekan deformation as complex networks of NNE-SSW and NW-SE trending faults and ESE-directed frontal thrust of the Eurekan Foldand-Thrust Belt [35]. In some areas, the faults were reactivated during SE-directed thrust tectonics in Mid-Eocene 
times (chron 21, [37]). Tegner et al. [42] concluded, based on new Ar-40-Ar-39 dating of alkaline volcanics from Kap Kane (part of the Kap Washington Group volcanics at the northern tip of Greenland), that the compression in North Greenland peaked at 49-47 Ma and coincided with the Eurekan Orogeny in a belt across the Canadian Arctic Islands and western Svalbard.

The idea of Eurekan deformation affecting areas beyond the Ellesmere Islands has been put forward in recent studies which combined knowledge of crustal structure from new geophysical data with results from modeling, and shows that the oceanic Amundsen Basin, the continental Lomonosov Ridge and the Morris Jessup Rise were all disturbed by significant Eurekan compression [10]. In particular, Dossing et al. [9] suggested that Eurekan crustal shortening contributed to the formation of the distinct Lomonosov Ridge plateau against an important fault zone north of Greenland.

Following this lead, we compute the Eocene-Oligocene motion of Greenland relative to Lomonosov Ridge (Fig. 5b), using a combined plate tectonic model based on dense magnetic anomaly identifications in the North Atlantic [16, 30]. Regional plate tectonic reconstructions and computed motion vectors are shown in Fig. 6. Two distinct periods of compression-transpression occurred between 54 and $49 \mathrm{Ma}$ (ca. $30 \mathrm{~mm} /$ year convergence velocity) and between 49 and $33 \mathrm{Ma}$ (ca. $13.5 \mathrm{~mm} / \mathrm{year}$ convergence velocity), and amounted to more than $350 \mathrm{~km}$ of oblique shortening between Greenland and Lomonosov Ridge (computed at the Siberian side of the ridge).
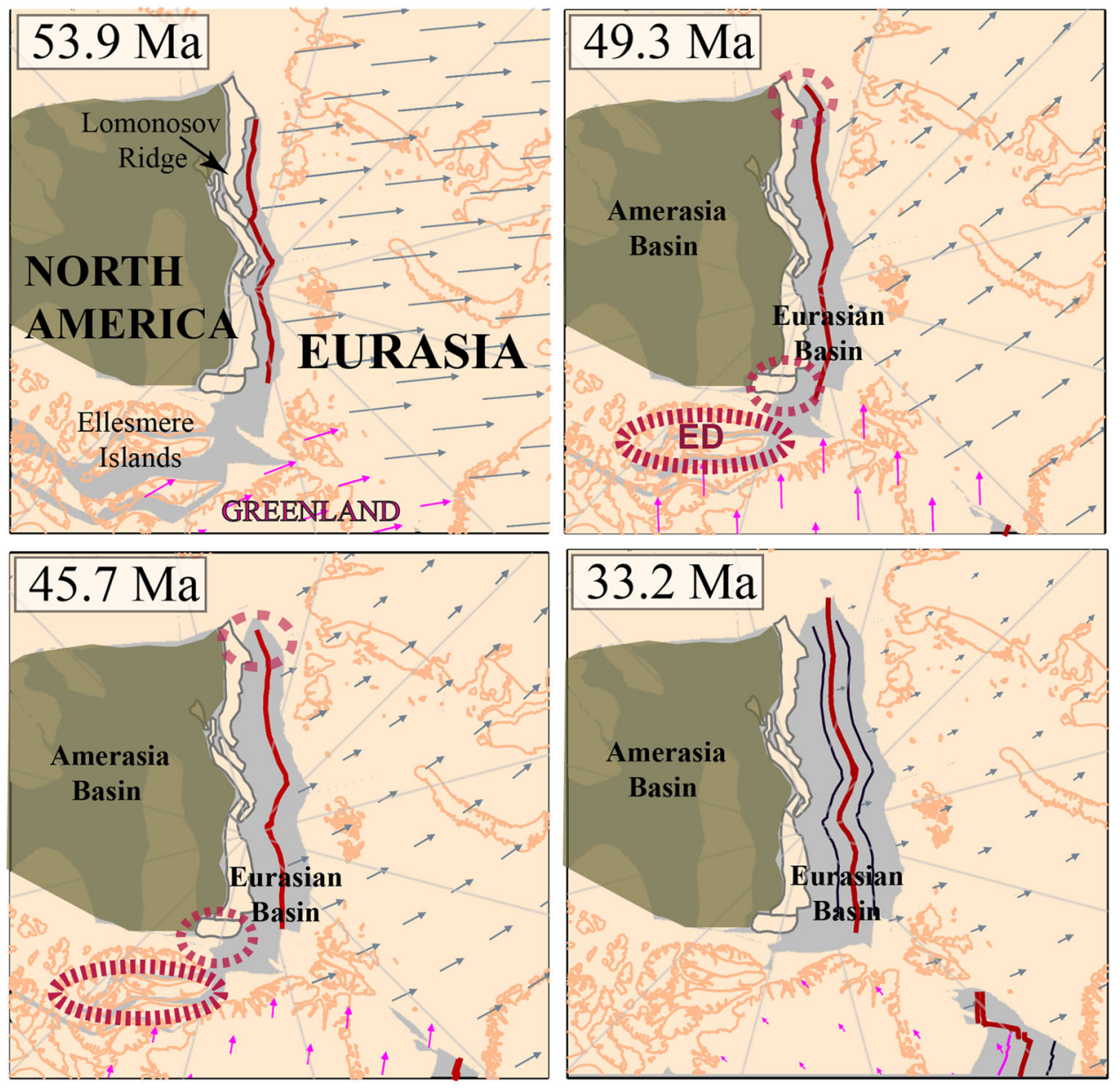

Fig. 6 Motion vectors of the Greenland (magenta), and Eurasian (grey) plates relative to the Lomonosov Ridge (North American plate) based on a regional model (modified after [16]). Red lines show the position of the mid ocean ridge at each reconstruction time. Note the change in the ridge orientation in the easternmost part of Eurasian Basin at 49.3 Ma and again at 33.2 Ma (for comparison, in the lower right panel, the isochrons for $45.7 \mathrm{Ma}$ are shown together with the ridge location at $33.2 \mathrm{Ma}$ ). Pale orange colour indicates continental crust and the grey area show oceanic basins (except the regions

around the Ellesmere Islands were the grey region shows future deformation area due to the Eurekan event). Areas affected by Eurekan deformation (ED)-including the one postulated in this study - are indicated by dashed lines redellipses. The extent of the Amerasian Basin is also shown, but we do not discuss here the nature of the crust in this region. The continent-ocean boundaries, including the outline of the Lomonosov Ridge, are based on potential field data (CAMP-GM, [17]) 
Combined with our interpretation and dating of compressional features imaged by the seismic data in the Laptev Sea and East Siberian Shelf, and the changes in seafloor spreading in the easternmost part of the Eurasian basin, these results point to possible links to one or several phases of the Eurekan deformation.

\section{Discussion}

Convergent plate-margin processes impose significant forces on the edges of continental blocks, often triggering intraplate stress field (e.g., [41, 45]). Mechanical and thermal differences in the strength of the lithosphere, additional stress fields due to mantle processes and gravitational potential resulted from changes in topography/bathymetry, the distance from plate boundaries, and other factors play an important role in the determination of the resultant lithospheric strain. Also note that the style of intraplate deformation resulting from convergence can include shortening, strike-slip, and extension-dominated regimes [41]. Despite numerous attempts to model how the stress field propagates away from various plate boundaries, there is no general model to prescribe how the intra-continental lithosphere responds to stresses as each case depends on specific rheology, loads and geometry. In our case, the continental nature and same thickness (ca. $20 \mathrm{~km}$ ) of the Lomonosov Ridge and adjacent extended continental crust from the Podvodnikov Basin and East Siberian Shelf may have been rheologically weaker and prone to be deformed easier than the cold oceanic crust formed at the ultraslow mid-ocean ridge in the Eurasian Basin.

Dossing et al. [9] suggested that the Eurekan event may have affected the southern part of the Lomonosov Ridge and also could have triggered a certain amount of compression in the southern Eurasian Basin that resulted in volcanism and even subduction. The lack of fracture zones in the Eurasian Basin makes it difficult to track changes in spreading direction, but we would like to point out that a certain change in isochron orientation is visible in the magnetic anomaly data northwest of the Kara Sea (Fig. 5, oval region marked with dashed black line). This pattern is more difficult to see on the conjugate flank in the Amundsen Basin, but a fan-shaped pattern for C24-C13 is not excluded. This tentative interpretation could indicate another gradual change in spreading direction from $\mathrm{C} 24$ or younger to $\mathrm{C} 13$ when the spreading direction stabilized and continued until present day. We do not have an explanation of why the spreading in the Eurasian Basin changed direction only in the middle and easternmost part of the basin, but speculate that this is connected to the basin architecture inherited from the continental margin prebreakup segmentation.
We also note that, according to our interpretation, the compressional regime lasted longer (to Early Miocene?) in the extended continental part (as seen on seismic lines in Figs. 2, 3, S1-4), but the oceanic spreading system has evolved steadily since Early Oligocene (ca. 33 Ma). Drachev et al. [11] interpreted thrusts and reverse faults in the so-called seismic unit SU-4 in the Laptev Sea and linked it with observed compressional features onshore on the New Siberian Islands and tentatively dated them as Oligocene to Middle Miocene, based on plate tectonic model predictions. A more detailed plate tectonic model based on magnetic anomaly data along the entire North AmericanEurasian plate boundary, implies that the tectonic regime between these two plates in the Laptev Sea region, was mostly extensional, with a slight transtensional component at chron 22 (ca. $49 \mathrm{Ma}$ ) [16]. This may hint that the identified SU-4 horizon could be older than Oligocene and that the Laptev Sea region that may have been affected by Eocene far-field stresses. Drachev et al. [11] interpretation of compressional features in the Laptev Sea has been challenged by Franke and Hinz [14] who interpreted only negligible evidence of the Oligocene-Miocene compression.

Our postulated change in the Gakkel Ridge spreading direction from ca. 49 to ca. $33 \mathrm{Ma}$ is in the opposite direction of the rift depocenter migration in the Laptev Sea, as interpreted by Drachev et al. [11]. However, Franke and Hinz [14] mentioned that the Anisin Basin, situated in the eastern part of the Laptev Sea (Fig. 1), and considered the youngest rift, has a shallower arm west of it that may indicate a rift migration westward. Unfortunately, the lack of drill holes in the Laptev Sea introduces significant uncertainties in the dating the rift events and subsequent sedimentation episodes.

\section{Conclusions}

We have interpreted selected profiles from the new seismic data collected by Russian institutes and inspected improved potential field grids in the easternmost part of Eurasian Basin, the East Siberian Shelf and adjacent regions of the Laptev Sea and Podvodnikov basin in order to identify possible post break-up changes in tectonic regimes. The oceanic crust (identified from the new seismic reflection data) in the easternmost part of Eurasian Basin displays an asymmetric fabric (visible in the gravity and magnetic gridded data), with the Gakkel ridge propagating obliquely relative to it. Tentative dating of the weak magnetic anomalies suggests asymmetric spreading or ridge relocation from ca. 49 to $33 \mathrm{Ma}$.

Three seismic reflection transects through the Laptev Sea, Lomonosov Ridge and adjacent basins display several 
compressional features including sedimentary package folding that may have been formed from the Eocene time onwards. Plate tectonic motion vectors based on up-to-date regional tectonic models indicate that the Greenland plate has impinged on the Lomonosov Ridge by ca. $30 \mathrm{~mm} /$ year from 54 to $49 \mathrm{Ma}$ and by ca. $13.5 \mathrm{~mm} /$ year and may have created transpression in the eastern Arctic (Fig. 6).

We therefore suggest that intraplate stresses triggered by the northern movement of the Greenland plate and collision with the North American plate in the Ellesmere Islands and western end of the Lomonosov Ridge have propagated through the Arctic region and affected part of the East Siberian Shelf, Podvodnikov Basin, Laptev Sea and modified the spreading direction in the eastern Eurasia Basin. We estimate that these changes started at the same time as the peak compressional phase in North Greenland dated at 49-47 Ma and lasted no later than Oligocene time when the large-scale tectonic regime changed by incorporating Greenland into the North American plate. These events preceded two major periods when the spreading rates in the Eurasian Basin decreased dramatically: at ca. 45 and 33 Ma (e.g., [19], see Fig. S5) and transformed this system in the slowest spreading ridge on Earth. Uncertainties linked to dating of this deformation are due to the lack of well data in the studied area, but numerical modeling may be used to test the proposed scenario.

Acknowledgments Seismic data acquisition, processing and interpretation was organized and funded by the Russian government and we thank Yu Kazmin and the Ministry of Natural Resources and Environment of the Russian Federation. Open source software GMT (gmt.soest.hawaii.edu) and GPlates (http://www.gplates.org) have been used for producing maps and tectonic reconstructions, respectively. C.G. acknowledges support from the Research Council of Norway through its Centers of Excellence funding scheme, Project Number 223272, and Norwegian-Russian collaboration funding scheme, Project Number 225027. We thank Olga Aleshina for assistance in the seismic data interpretation.

\section{References}

1. Amante C, BW Eakins (2009) ETOPO1 1 arc-minute global relief model: procedures, data sources and analysis. Rep, $19 \mathrm{pp}$, NGDC

2. Alvey A, Gaina C, Kusznir NJ, Torsvik TH (2008) Integrated crustal thickness mapping and plate reconstructions for the high Arctic. Earth Planet Sci Lett 274(3-4):310-321

3. Andersen OB (2010) The DTU10 Gravity field and Mean sea surface, in Second international symposium of the gravity field of the Earth (IGFS2), edited. Fairbanks, Alaska

4. Backman J et al (2008) Age model and core-seismic integration for the Cenozoic Arctic Coring Expedition sediments from the Lomonosov Ridge. Paleoceanography 23:1

5. Balmino G, Vales N, Bonvalot S, Briais A (2011) Spherical harmonic modeling to ultra-high degree of Bouguer and isostatic anomalies. J Geodesy 86:499-520. doi:10.1007/s00190-0110533-4
6. Brozena JM, Childers VA, Lawver LA, Gahagan LM, Forsberg R, Faleide JI, Eldholm O (2003) New aerogeophysical study of the Eurasia Basin and Lomonosov Ridge: implications for basin development. Geology 31(9):825-828

7. Cochran JR, Edwards MH, Coakley BJ (2006) Morphology and structure of the Lomonosov Ridge. Arctic Ocean, Geochem Geophy Geosy 7

8. Dick HJB, Snow J, Michael PJ, Hellebrand EH, Shimizu N, Hofmann A (2004) Gakkel Ridge: mantle and melting at ultraslow spreading rates. Geochim Cosmochim Ac 68(11):A691A691

9. Dossing A, Hopper JR, Olesen AV, Rasmussen TM, Halpenny J (2013) New aero-gravity results from the Arctic: linking the latest Cretaceous-early Cenozoic plate kinematics of the North Atlantic and Arctic Ocean. Geochem Geophy Geosy 14(10):4044-4065

10. Dossing A, Hansen TM, Olesen AV, Hopper JR, Funck T (2014) Gravity inversion predicts the nature of the Amundsen Basin and its continental borderlands near Greenland. Earth Planet Sc Lett 408:132-145

11. Drachev SS, Savostin LA, Groshev VG, Bruni IE (1998) Structure and geology of the continental shelf of the Laptev sea, eastern Russian Arctic. Tectonophysics 298(4):357

12. Engen O, Gjengedal JA, Faleide JI, Kristoffersen Y, Eldholm O (2009) Seismic stratigraphy and sediment thickness of the Nansen Basin, Arctic Ocean. Geophys J Int 176(3):805-821

13. Forsyth DA, Mair JA (1984) Crustal Structure of the Lomonosov Ridge and the Fram and Makarov Basins near the North-Pole. J Geophys Res 89(Nb1):473-481

14. Franke D, Hinz K (2005) The structural style of sedimentary basins on the shelves of the Laptev Sea and western East Siberian Sea, Siberian Arctic. J Petrol Geol 28(3):269-286

15. Franke D, Hinz K, Oncken O (2001) The Laptev Sea Rift. Mar Petrol Geol 18(10):1083-1127

16. Gaina C, Roest WR, Muller RD (2002) Late Cretaceous-Cenozoic deformation of northeast Asia. Earth Planet Sc Lett 197(3-4):273-286

17. Gaina C, Werner SC, Saltus R, Maus S (2011) Circum-Arctic mapping project: new magnetic and gravity anomaly maps of the Arctic. Geol Soc Lond Mem 35:39-48

18. Gaina C, Medvedev S, Torsvik TH, Koulakov I, Werner SC (2014) 4D Arctic: a glimpse into the structure and evolution of the arctic in the light of new geophysical maps, plate tectonics and tomographic models. Surv Geophys 35(5):1095-1122

19. Glebovsky VY, Kaminsky VD, Minakov AN, Merkur'ev SA, Childers VA, Brozena JM (2006) Formation of the Eurasia Basin in the arctic ocean as inferred from geohistorical analysis of the anomalous magnetic. Geotectonics 40(4):263-281

20. Glebovsky VY, Chernykh A, Kaminsky V, Poselov V, Litvinova T, Erinchek Y, Kashubin S, Gaina C, Smelror M (2011) Integrated analysis of updated potential field database: implications for the compilation of the new Circum-Arctic Tectonic Map, in ICAM VI, edited. Fairbanks, Alaska

21. Gradstein FM, Ogg JG, Schmitz M, Ogg G (2012) The geologic time scale 2012. Elsevier, Amsterdam 1176 pp

22. Jokat W, Ickrath M (2015) Structure of ridges and basins off East Siberia along 81 degrees N, Arctic Ocean. Mar Petrol Geol 64:222-232

23. Jokat W, Uenzelmannneben G, Kristoffersen Y, Rasmussen TM (1992) Lomonosov ridge-a double-sided continental-margin. Geology 20(10):887-890

24. Jokat W, Weigelt E, Kristoffersen Y, Rasmussen T, Schone T (1995) New Insights into the evolution of the Lomonosov ridge and the Eurasian Basin. Geophys J Int 122(2):378-392

25. Kashubin S, Petrov OV, Androsov EA (2011) Crustal thickness in the Circum Arctic. In: DB Stone, GE Grikurov, JG Clough, GN Oakey, DK Thurston (eds), ICAM VI: Proceedings of the 
International Conference on Arctic Margins VI. A.P. Karpinsky Russian Geological Research Institute (VSEGEI), Fairbanks, Alaska, May 2011, pp. 1-19

26. Kaminsky VD, Suprunenko OI, Suslova VV (2011) The continental shelf of the Russian Arctic region: the state of the art in the study and exploration of oil and gas resources. Russian Geology and Geophysics (Geologiya i Geophyzika) 52(8):760-767

27. Langinen AE, Lebedeva-Ivanova NN, Gee DG, Zamansky YY (2009) Correlations between the Lomonosov Ridge. Marvin Spur and adjacent basins of the Arctic Ocean based on seismic data, Tectonophysics 472(1-4):309-322

28. Lebedeva-Ivanova NN, Zamansky YY, Langinen AE, Sorokin MY (2006) Seismic profiling across the Mendeleev Ridge at 82 degrees $\mathrm{N}$ : evidence of continental crust. Geophys J Int 165(2):527-544

29. Lebedeva-Ivanova NN, C Gaina, A Minakov, S Kashubin (2015) A crustal thickness model of the Arctic Region, in EGU General Assembly 2015, edited, pp. EGU2015-3764, European Geophysical Union, Vienna, Austria

30. Merkouriev S, DeMets C (2014) High-resolution Quaternary and Neogene reconstructions of Eurasia-North America plate motion. Geophys J Int 198(1):366-384

31. Nikishin AM, Malyshev NA, Petrov EI (2014) Geological structure and history of the Arctic ocean. EAGE Publications, Houten

32. Oakey GN, Saltus RW, Chian D, Jackson HR, Shimeld J, Brozena JM, Funck T, Dahl-Jensen T (2013) Crustal structure and tectonic framework of the Canadian Arctic margin: new insights on the development of the Amerasia Basin, in American Geophysical Union Annual Convention 2013, edited. American Geophysical Union, San Francisco

33. Ogg JG (2012) The Geomagnetic Polarity Timescale. In: Gradstein FM, Ogg JG, Schmitz M, Ogg G (eds) The Geologic Time Scale 2012. Elsevier, Amsterdam, pp 85-115

34. Pease V, Drachev S, Stephenson R, Zhang X (2014) Arctic lithosphere-a review. Tectonophysics 628:1-25

35. Piepjohn K, von Gosen W, Laufer A, McClelland WC, Estrada S (2013) Ellesmerian and Eurekan fault tectonics at the northern margin of Ellesmere Island (Canadian High Arctic). Z Dtsch Ges Geowiss 164(1):81-105

36. Poselov VA, Avetisov GP, Butsenko VV, Zholondz SM, Kaminsky VD, Pavlov SP (2012) The Lomonosov Ridge as a natural extension of the Eurasian continental margin into the Arctic Basin. Russ Geol Geophys 53(12):1276-1290

37. Saalmann K, Tessensohn F, Piepjohn K, von Gosen W, Mayr U (2005) Structure of Palaeogene sediments in east Ellesmere Island: constraints on Eurekan tectonic evolution and implications for the Nares Strait problem. Tectonophysics 406(1-2):81-113

38. Sekretov SB (2002) Structure and tectonic evolution of the Southern Eurasia Basin Arctic Ocean. Tectonophysics 351(3): 193-890

39. Seton M, Muller RD, Zahirovic S, Gaina C, Torsvik TH, Shephard G, Talsma A, Gurnis M, Turner M, Maus S, Chandler M (2012) Global continental and ocean basin reconstructions since 200 Ma. Earth Sci Rev 113(3-4):212-270

40. Srivastava SP, Tapscott CR (1986) Plate kinematics of the North Atlantic. In: Vogt PR, Tucholke BE (eds) The western North Atlantic region. Geological Society of America, Boulder, pp 379-404

41. Tapponnier P, Molnar P (1976) Slip-Line Field-Theory and Large-Scale Continental Tectonics. Nature 264(5584):319-324

42. Tegner C, Storey M, Holm PM, Thorarinsson SB, Zhao X, Lo $\mathrm{CH}$, Knudsen MF (2011) Magmatism and Eurekan deformation in the High Arctic Large Igneous Province: ar-40-(39) age of Kap Washington Group volcanics. North Greenland, Earth Planet Sc Lett 303(3-4):203-214

43. von Gosen W, Piepjohn K, Reinhardt L (2012) Polyphase Eurekan deformation along the Vendom Fiord Fault Zone on south Ellesmere Island (Canadian Arctic) and its possible relation to the Wegener Fault. Z Dtsch Ges Geowiss 163(3):261-282

44. Weigelt E, Jokat W, Franke D (2014) Seismostratigraphy of the Siberian Sector of the Arctic Ocean and adjacent Laptev Sea Shelf. J Geophys Res-Sol Ea 119(7):5275-5289

45. Ziegler PA, van Wees JD, Cloetingh S (1998) Mechanical controls on collision-related compressional intraplate deformation. Tectonophysics 300(1-4):103-129 